\title{
Effect of a low-protein diet on the chemical composition of the bodies and tissues of young rats
}

\author{
By ELSIE M. WIDDOWSON AND R. A. MCCANCE \\ Medical Research Council Department of Experimental Medicine, \\ University of Cambridge \\ (Received I9 November 1956)
}

It might be expected that prolonged malnutrition due to a diet very low in protein would impoverish the cells in nitrogen. It has been stated, for example, or certainly implied, that impoverishment takes place in kwashiorkor (Trowell, Davies \& Dean, 1954; FAO/WHO/Josiah Macy Jr. Foundation, r955) and results in the substitution of water and of potassium salts for protein and enzymes. This would necessarily lead to gross chemical changes in the percentage composition of the tissues. In support of this view Holmes, Jones \& Stanier (1954) found that when African adults, who were grossly undernourished and who had been subsisting for long periods of time on very low protein intakes, were given generous high-protein diets they absorbed and retained great quantities of $\mathrm{N}$ but they did not gain nearly enough weight to account for this retention according to conventional views about the water-protein relationship of healthy tissues. This finding suggested that during rehabilitation considerable substitution of protein and enzymes for water and potassium salts was taking place within the cells (see also Gopalan, Venkatachalam \& Srikantia, I953; Passmore, Meiklejohn, Dewar \& Thow, I955; Anonymous, 1955).

None of these observations on man had been accompanied by analyses of tissues for nitrogen and potassium. To add to the existing evidence a study has been made of the effects of very low protein intakes in young male rats on the weight and chemical structure of their bodies and tissues.

\section{EXPERIMENTAL,}

Three experiments have been carried out and the vitamin and mineral requirements of all the animals have been satisfied throughout. In the first, six rats, 4 weeks old with a mean weight of $60 \mathrm{~g}$ were given a low-protein diet consisting of cassava and banana in unlimited amounts. On this diet the animals lost weight; they were killed after 14 days. Six rats, which were to serve for 'weight' comparisons, were given a high-protein diet consisting of full-cream dried milk and fish meal (the high-protein, low-calorie diet) in amounts so limited that their mean weight was kept within a few grams of that of the animals of the first group. Six rats, which served as positive controls, were given a $\mathrm{I}: \mathrm{I}$ mixture of the low-protein and high-protein diets (the control mixture) in unlimited amounts.

The second experiment was planned to repeat the first and in addition to reproduce, if possible, the observations of Holmes et al. (1954) during rehabilitation in man. In 
this experiment there were initially eleven animals in each group; their age was 5 weeks and their mean weight $73 \mathrm{~g}$. The diets were the same as before and the duration of the period of deprivation was also the same. After it was over some of the animals from each group were killed for analysis and the remainder were all given unlimited amounts of the 'control mixture' for a further 3 weeks, after which they were all killed and analysed.

The third experiment was made after the results of the first two experiments were available, and it had become clear that no excessive amounts of $\mathrm{N}$ were being deposited in the tissues during rehabilitation on the 'control mixture' diet. It was decided to give young rats a further opportunity of retaining $\mathrm{N}$ by rehabilitating them on unlimited amounts of the high-protein diet. The experiment was conducted on animals $3^{-4}$ weeks old at the beginning with a mean weight of $3^{8} \mathrm{~g}$. There were ten animals in each group. The diets were the same and the treatment was the same for the first 2 weeks, but no animals were killed after the I4-day deprivation period. The animals that had been living on the low-protein diet and those that had been living on the highprotein, low-calorie diet were then given the high-protein diet in unlimited amounts for 4 weeks and were killed for analysis. The positive control animals that had been eating the 'control mixture' for 6 weeks were killed for analysis at the same time.

\section{The diets}

The low-protein diet. Cassava flour bought in Kampala, the same as that eaten by Africans living in Uganda, formed the basis of the diet. Cassava, $80 \mathrm{~g}$, was mixed with $160 \mathrm{ml}$. boiling water, half a banana was mashed into the mixture and $5 \mathrm{~g}$ salt mixture (British Drug Houses Ltd) and $70 \mathrm{mg}$ of a vitamin B-complex powder (Crookes Laboratories $L t d$ ), dissolved in water, were stirred in. This quantity was ample for eleven or twelve rats and the diet was fed ad lib. The dry diet contained $1.5 \%$ protein.

The high-protein, low-calorie diet. Dried full-cream milk powder, $20 \mathrm{~g}$, and fish meal, $20 \mathrm{~g}$, were mixed with $50 \mathrm{ml}$. water, and $5 \mathrm{~g} \mathrm{B.D.H}$. salt mixture and $70 \mathrm{mg}$ of the $\mathrm{B}$-vitamins powder were added. The dry diet contained $45 \%$ of protein. The quantity of the diet fed was such as would maintain the weights of the animals the same as those of the rats having the low-protein diet. 'The rats in this group were kept and fed in individual cages.

The 'control mixture' diet. It consisted of a mixture of $80 \mathrm{~g}$ cassava, $20 \mathrm{~g}$ dried-milk powder, $20 \mathrm{~g}$ fish meal with $200 \mathrm{ml}$. water, half a banana, $5 \mathrm{~g}$ B.D.H. salt mixture and $70 \mathrm{mg}$ of the B-vitamins powder. The dry diet contained $15.8 \%$ protein. This diet, like the low-protein diet, was fed ad lib.

\section{Killing and dissection of the animals}

The rats were anaesthetized with pentobarbitone sodium (B.P.). A piece of muscle was taken from the thigh and weighed, the livers were removed and weighed, and the remainders of the bodies were weighed, cut up and minced several times, and sampled for analysis. The muscle was cut up finely with scissors before sampling and the livers were homogenized. 


\section{Chemical methods}

Water was determined on samples of the muscle, liver and carcass by drying to constant weight at $100^{\circ}$. These samples were then ashed at $45^{\circ}$, the ash was extracted with $\mathrm{HCl}$ as described by $\mathrm{McCance}$, Widdowson \& Shackleton (1936) and the acid extract of the ash used for the estimation of sodium, potassium and phosphorus. $\mathrm{N}$ was determined on another sample by the micro-Kjeldahl technique after digestion with $\mathrm{H}_{2} \mathrm{SO}_{4}$ and copper selenide, and fat was estimated by saponification with alcoholic soda as described by McCance \& Shipp (1933). Chloride was determined on weighed samples of the tissues $\left(0.5^{-2} \mathrm{~g}\right)$ by digesting with conc. $\mathrm{HNO}_{3}$ and 5 or $10 \mathrm{ml}$. of $0.02 \mathrm{~N}-\mathrm{AgNO}_{3}$ and titrating the excess $\mathrm{AgNO}_{3}$ with $0.02 \mathrm{~N}-\mathrm{KCNS}$ in the presence of ferric sulphate.

$\mathrm{Na}$ was estimated with a Beckman flame photometer, but $\mathrm{K}$ was determined chemically with sodium cobaltinitrite (McCance \& Shipp, 1933) since it has been found that the results obtained with the flame photometer for $\mathrm{K}$ in animal tissues were consistently too low. $\mathrm{P}$ was estimated on a portion of the acid extract of the ash after heating in a boiling water-bath with a few drops of conc. $\mathrm{H}_{2} \mathrm{SO}_{4}$ for $\mathrm{I} h$ to convert any pyrophosphate to orthophosphate. The method described by King (1932) was used for the development of the colour.

\section{RESULTS}

Animals on the 'control mixture' diet in unlimited amounts all throve and grew satisfactorily. Animals on the low-protein diet lost a little weight, although there was always food before them, but they did not die before the end of the 14 days for which they were subjected to this régime. The animals fed on restricted amounts of the high-protein diet, however, began to die after the end of the rst week, and this mortality reduced their numbers and limited the length of time for which the others were given the low-protein diet. Two out of six died in the first experiment, four out of eleven in the second and four out of ten in the third. The reason for this mortality on a high-protein diet and survival on a diet very low in protein is unknown.

Figs. I and 2 show the effects of these diets and experimental procedures on the weights of the experimental animals. 'The growth on the 'control mixture' diet and the losses of weight on the other two diets, followed by the effects of rehabilitation on the 'control mixture' diet and on the high-protein diet are shown. It is to be noted that, although the animals tended to die on restricted amounts of the high-protein diet, they grew satisfactorily on unlimited amounts of it during the rehabilitation period (Fig. 2).

Table I shows the effects of the three diets on the total $\mathrm{N}$ in the bodies of the rats that were killed at the end of the period of deprivation in Exps. I and 2 and of their positive controls. It also shows the way in which the $\mathrm{N}$ was distributed between the liver and the rest of the body at death. The large amount in the bodies of those on the 'control mixture' diet was an expression of the animals' growth (see Fig. I). The livers made up $5.3 \%$ of the body-weight of these animals and contained on average I $86 \mathrm{mg}$ $\mathrm{N}$. The low-protein animals had only one-third as much $\mathrm{N}$ in their livers, and the organs were not enlarged and swollen with fat for they weighed only about $2 \cdot 4 \mathrm{~g}$ 
( $4.5 \%$ of the body-weight). The high-protein, low-calorie rats with the same bodyweight as the low-protein animals had larger livers, which weighed about $4 \mathrm{~g} \mathrm{(7.3 \%}$ of the body-weight) and contained $142 \mathrm{mg} \mathrm{N}$. This was not far short of the amounts in the livers of the animals on the 'control mixture' diets, which had shown satisfactory somatic growth. The effects of the three diets on the percentage of $\mathrm{N}$ in the liver are shown in the penultimate column, and in the last column the percentage of $\mathrm{N}$ in the fat-free carcasses, excluding the liver. It is clear that, whereas the animals on the highprotein, low-calorie diet had larger livers and a high concentration of $\mathrm{N}$ in them, the composition of the rest of the body was the same in all three groups.

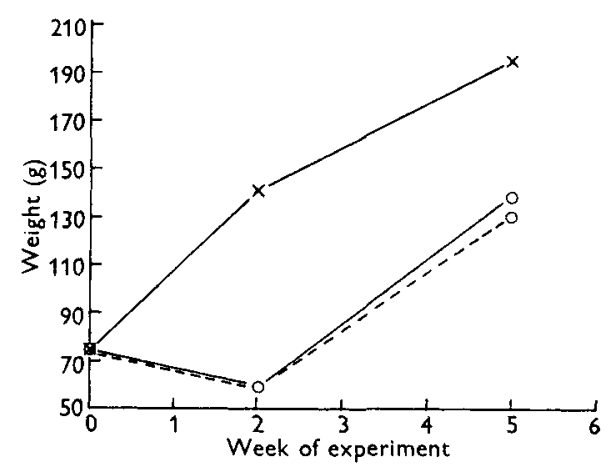

Fig. I

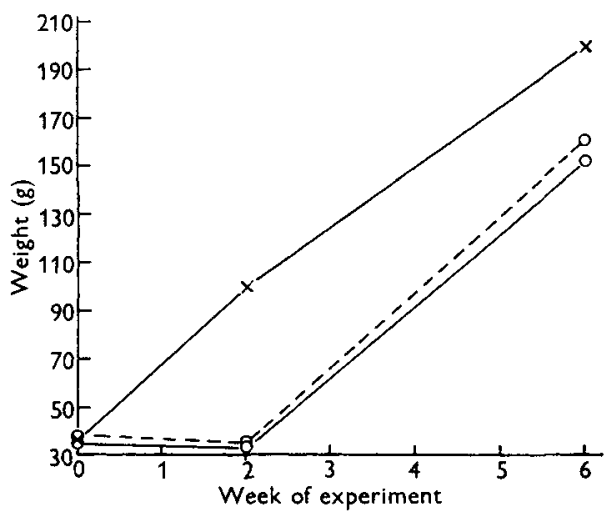

Fig. 2

Fig. I. Mean weights of rats in Exp. 2. -0 , low-protein diet for 2 weeks then 'control mixture'* diet for 3 weeks; $0---0$, high-protein, low-calorie diet for 2 weeks then 'control mixture'* diet for 3 weeks; $x-x$, 'control mixture'* diet for 5 weeks.

* A I : I mixture of the low-protein and the high-protein diets.

Fig. 2. Mean weights of rats in Exp. 3. $0-0$, low-protein diet for 2 weeks, then high-protein diet in unlimited amounts for 4 weeks; $0---\circ$, high-protein, low-calorie diet for 2 weeks then highprotein diet in unlimited amounts for 4 weeks; $x-x$, 'control mixture'* diet for 6 weeks.

* A 1:1 mixture of the low-protein and the high-protein diets.

Table 1. Effect of low-protein diet on the nitrogen in the body and liver of rats

(Mean values for groups)

\begin{tabular}{|c|c|c|c|c|c|c|c|c|}
\hline \multirow[b]{2}{*}{ Diet } & \multirow{2}{*}{$\begin{array}{l}\text { Exp. } \\
\text { no. }\end{array}$} & \multirow{2}{*}{$\begin{array}{l}\text { No. of } \\
\text { rats/group }\end{array}$} & \multirow{2}{*}{$\begin{array}{l}\text { Body- } \\
\text { weight } \\
\text { (g) }\end{array}$} & \multirow{2}{*}{$\begin{array}{l}\mathrm{N} \text { in } \\
\text { body } \\
(\mathrm{mg})\end{array}$} & \multirow{2}{*}{$\begin{array}{l}\text { Wt. of } \\
\text { liver } \\
\text { (g) }\end{array}$} & \multicolumn{2}{|c|}{$N$ in liver } & \multirow{2}{*}{$\begin{array}{l}\mathrm{N} \text { in fat-free } \\
\text { carcass (exclud- } \\
\text { ing liver) } \\
(\mathrm{g} / 100 \mathrm{~g})\end{array}$} \\
\hline & & & & & & $\mathrm{mg}$ & $\mathrm{g} / \mathrm{I} 00 \mathrm{~g}$ & \\
\hline Low-protein & $\begin{array}{l}\mathbf{I} \\
2\end{array}$ & $\begin{array}{l}6 \\
6\end{array}$ & $\begin{array}{l}50 \\
58\end{array}$ & $\begin{array}{l}1470 \\
1760\end{array}$ & $\begin{array}{l}2 \cdot 53 \\
2 \cdot 29\end{array}$ & $\begin{array}{l}65 \cdot 3 \\
50 \cdot 9\end{array}$ & $\begin{array}{l}2 \cdot 59 \\
2 \cdot 22\end{array}$ & $\begin{array}{l}3 \cdot 12 \\
3 \cdot 30\end{array}$ \\
\hline $\begin{array}{l}\text { High-protein, } \\
\text { low-calorie }\end{array}$ & $\begin{array}{l}\text { I } \\
2\end{array}$ & $\begin{array}{l}4 \\
4\end{array}$ & $\begin{array}{l}53 \\
58\end{array}$ & $\begin{array}{l}1710 \\
1880\end{array}$ & $\begin{array}{l}4^{\cdot 1} 5 \\
3 \cdot 94\end{array}$ & $\begin{array}{l}143^{\circ} \circ \\
141^{\circ} 0\end{array}$ & $\begin{array}{l}3.45 \\
3.58\end{array}$ & $\begin{array}{l}3 \cdot 20 \\
3 \cdot 28\end{array}$ \\
\hline 'Control mixture'* & $\begin{array}{l}\text { I } \\
2\end{array}$ & $\begin{array}{l}6 \\
6\end{array}$ & $\begin{array}{r}99 \\
139\end{array}$ & $\begin{array}{l}2870 \\
4030\end{array}$ & $\begin{array}{l}5 \cdot 19 \\
7 \cdot 36\end{array}$ & $\begin{array}{l}151 \cdot 0 \\
220 \cdot 0\end{array}$ & $\begin{array}{l}2 \cdot 92 \\
3 \cdot 00\end{array}$ & $\begin{array}{l}3 \cdot 10 \\
3 \cdot 28\end{array}$ \\
\hline
\end{tabular}

* A I : I mixture of the low-protein and the high-protein diets.

Table 2 shows the composition of the skeletal muscle and of the liver after the rats had been living for 2 weeks on the low-protein diet, the high-protein, low-calorie diet, and unlimited amounts of the 'control mixture'. The results obtained in Exps. I and 2 
have been averaged. The values for the cellular constituents of the well-nourished animals often tended to fall between those for the low-protein animals and their weight controls on the high-protein, low-calorie diet. This relationship applies to the percentage of protein in the liver, to the concentration of $\mathrm{K}$ in the muscle and to the $\mathrm{N}: \mathrm{K}$ and $\mathrm{N}: \mathrm{P}$ ratios.

A different sequence was found among the extracellular ions, $\mathrm{Na}$ and $\mathrm{Cl}$. The muscles of the well-nourished positive controls contained less $\mathrm{Cl}$ than those of the lowprotein animals and these again less than those of the high-protein, low-calorie groups. The livers of the last group also contained a higher concentration of $\mathrm{Cl}$ and $\mathrm{Na}$ than either of the others.

Table 2. Effect of a low-protein diet on the composition of skeletal muscle and liver of rats

(Mean values for groups)

\begin{tabular}{|c|c|c|c|c|c|c|c|c|c|}
\hline \multirow[b]{2}{*}{ Diet } & \multirow{2}{*}{$\begin{array}{l}\text { No. of } \\
\text { rats/ } \\
\text { group }\end{array}$} & \multirow{2}{*}{$\begin{array}{l}\text { Water } \\
\text { (g/100 g) }\end{array}$} & \multirow{2}{*}{$\begin{array}{l}N \times 6.25 \\
(g / 100 \mathrm{~g})\end{array}$} & \multirow{2}{*}{$\begin{array}{c}\mathrm{K} \\
(\mathrm{mg} / \\
\mathrm{I} 00 \mathrm{~g})\end{array}$} & \multirow{2}{*}{$\begin{array}{c}P \\
(\mathrm{mg} / \\
\mathrm{I} 00 \mathrm{~g})\end{array}$} & \multirow{2}{*}{$\begin{array}{c}\mathrm{Na} \\
(\mathrm{mg} / \\
100 \mathrm{~g})\end{array}$} & \multirow{2}{*}{$\begin{array}{c}\mathrm{Cl} \\
(\mathrm{mg} / \\
100 \mathrm{~g})\end{array}$} & \multicolumn{2}{|c|}{ Ratio } \\
\hline & & & & & & & & $\mathrm{N}: \mathrm{K}$ & $N: P$ \\
\hline \multicolumn{10}{|c|}{ Skeletal muscle } \\
\hline Low-protein & 12 & $74 \cdot I$ & $19 \cdot 0$ & 477 & 243 & 64 & 87 & $6 \cdot 4$ & $12 \cdot 6$ \\
\hline $\begin{array}{l}\text { High-protein, low- } \\
\text { calorie }\end{array}$ & 8 & $76 \cdot 6$ & $19 \cdot 8$ & $44^{\circ}$ & 243 & 72 & 103 & $7 \cdot 2$ & I $3 \cdot 1$ \\
\hline Control mixture'* & 12 & $74 \cdot 8$ & $18 \cdot 9$ & 457 & 243 & $4^{8}$ & 77 & $6 \cdot 6$ & $12 \cdot 5$ \\
\hline \multicolumn{10}{|c|}{ Liver } \\
\hline Low-protein & 12 & $74^{\circ} \mathrm{I}$ & $15 \cdot \mathrm{I}$ & $35^{6}$ & 290 & 90 & 144 & $6 \cdot 8$ & $8 \cdot 3$ \\
\hline $\begin{array}{l}\text { High-protein, low- } \\
\text { calorie }\end{array}$ & 8 & $73 \cdot 9$ & $22 \cdot 0$ & 353 & 318 & 97 & I 55 & $10 \cdot 0$ & II $1 \cdot 1$ \\
\hline 'Control mixture'* & 12 & $74 \cdot 2$ & $18 \cdot 6$ & 357 & 320 & 90 & 142 & $8 \cdot 3$ & $9 \cdot 3$ \\
\hline
\end{tabular}

* A I : I mixture of the low-protein and the high-protein diets.

Table 3 shows the $\mathrm{N}$ in the body and liver after rehabilitation on the 'control mixture' and the high-protein diets, arranged in the same fashion as in Table I. After

Table 3. Nitrogen in the body and liver of rats after rehabilitation on the "control mixture'* and the high-protein diets

(Mean values for groups)

\begin{tabular}{|c|c|c|c|c|c|c|c|c|c|}
\hline \multirow{2}{*}{$\begin{array}{l}\text { Exp. } \\
\text { no. }\end{array}$} & \multicolumn{2}{|c|}{ Diet } & \multirow{2}{*}{$\begin{array}{l}\text { No. of } \\
\text { rats } / \\
\text { group }\end{array}$} & \multirow{2}{*}{$\begin{array}{l}\text { Body- } \\
\text { weight } \\
\text { (g) }\end{array}$} & \multirow{2}{*}{$\begin{array}{l}\mathrm{N} \text { in } \\
\text { body } \\
(\mathrm{mg})\end{array}$} & \multirow{2}{*}{$\begin{array}{l}\text { Wt. of } \\
\text { liver } \\
\text { (g) }\end{array}$} & \multicolumn{2}{|c|}{$\mathrm{N}$ in liver } & \multirow{2}{*}{$\begin{array}{l}\text { carcass } \\
\text { (excluding } \\
\text { liver) } \\
(\mathrm{g} / \mathrm{l} 00 \mathrm{~g})\end{array}$} \\
\hline & Original & Rehabilitation & & & & & $\mathrm{mg}$ & $\mathrm{g} / 100 \mathrm{~g}$ & \\
\hline 2 & Low-protein & 'Control mixture'* & 5 & 138 & $3^{8} 5^{\circ}$ & IO' I & 327 & $3 \cdot 24$ & 3.04 \\
\hline & $\begin{array}{l}\text { High-protein, } \\
\text { low-calorie }\end{array}$ & & 3 & I 30 & 3720 & $8 \cdot 7$ & 313 & $3 \cdot 60$ & $3 \cdot 13$ \\
\hline & 'Control mixture'* & & 5 & I 94 & 5800 & $10 \cdot 3$ & 320 & $3 \cdot 10$ & $3 \cdot 45$ \\
\hline 3 & $\begin{array}{l}\text { Low-protein } \\
\text { High-protein, } \\
\text { low-calorie }\end{array}$ & High-protein & $\begin{array}{r}10 \\
6\end{array}$ & $\begin{array}{l}151 \\
160\end{array}$ & $\begin{array}{l}4700 \\
4500\end{array}$ & $\begin{array}{l}12 \cdot 8 \\
12 \cdot 6\end{array}$ & $\begin{array}{l}408 \\
393\end{array}$ & $\begin{array}{l}3.19 \\
3 \cdot 12\end{array}$ & $\begin{array}{l}3.4 I \\
3 \cdot 28\end{array}$ \\
\hline & 'Control mixture'* & 'Control mixture'* & 10 & 198 & 5890 & 10.4 & 315 & $3 \cdot 04$ & $3 \cdot 49$ \\
\hline
\end{tabular}

* A I : I mixture of the low-protein and the high-protein diets. 
rehabilitation on both diets the low-protein animals were heavier and they contained more $\mathrm{N}$ than their weight controls on the high-protein, low-calorie diet. They also contained more $\mathrm{K}$ ( $4 \mathrm{II} \mathrm{mg} \mathrm{against} 389 \mathrm{mg}$ in Exp. 2), and if it is assumed that the composition of the bodies of the animals that were killed at the end of the period of deprivation was identical with that of the animals in the same group that were subsequently rehabilitated, the $\mathrm{N}: \mathrm{K}$ ratio of the added body tissue was very similar in the two groups $(8.6$ for the low-protein animals and 8.8 for the animals that had previously been having the high-protein, low-calorie diet). The percentage of $\mathrm{N}$ in the added body tissue was exactly the same in the two groups $(2 \cdot 6 \%)$. The livers of the lowprotein animals after rehabilitation were heavier and contained slightly more $\mathrm{N}$. The percentage of $\mathrm{N}$ in the liver was not higher after rehabilitation for 4 weeks on the highprotein diet, but the livers were larger so the total amount of $\mathrm{N}$ in them was greater, as compared with that in the animals that had been rehabilitated for 3 weeks on the 'control mixture' diet.

Since the animals subjected to the low-protein diet and their weight controls on the high-protein, low-calorie diet had not yet grown to the size of the well-nourished controls, the values for the total amounts of $\mathrm{N}$ in their bodies were naturally lower. As might have been expected, the animals that had been rehabilitated on the high-protein diet for 4 weeks were nearer to their well-nourished positive controls than those rehabilitated on the 'control mixture' diet for 3 weeks as regards body-weight, and also in the percentage of $\mathrm{N}$ in the fat-free carcasses.

Table 4 shows the composition of the skeletal muscle and liver after rehabilitation on both types of diet. The skeletal muscles of the low-protein animals contained slightly more water and less protein than those of the animals in the high-protein, lowcalorie group after rehabilitation on the 'control mixture' diet, but, generally speaking, the effects of the low-protein and the high-protein, low-calorie diets had largely been eliminated during the rehabilitation period and, except that there was still more $\mathrm{Na}$ and $\mathrm{Cl}$ in the muscles of the high-protein, low-calorie animals after rehabilitation on the 'control mixture' diet, the composition both of muscle and liver was very similar whatever the initial treatment or rehabilitation diet had been.

\section{DISCUSSION}

The effects of a low-protein diet. If the values for the muscle are considered first, the indications are that, although the animals did not grow on the low-protein diet, their muscles did not alter much in composition as compared with those of the wellnourished controls. Their cells did not lose protein and take up water and $\mathrm{K}$ salts to maintain their volume, for there was no fall in the $\mathrm{N}: \mathrm{K}$ ratio. The values for the highprotein, low-calorie animals suggest that, although they were the most undernourished as judged by the concentration of $\mathrm{Cl}-$ i.e. extracellular water-in the muscles, the cells may have contained more $\mathrm{N} / \mathrm{unit}$ volume than those of the rats in either of the other groups, for the muscles of these animals had higher $\mathrm{N}: \mathrm{K}$ and $\mathrm{N}: \mathrm{P}$ ratios than either of the others. Without figures for the collagen and other extracellular N, however, it is impossible to be sure of it. 


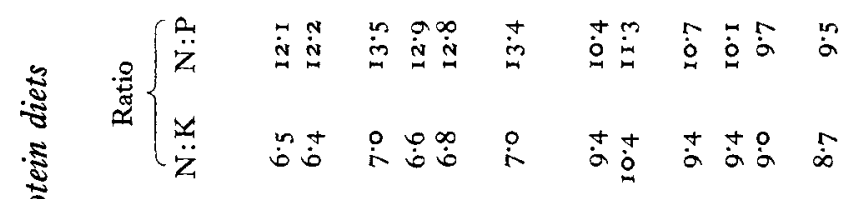

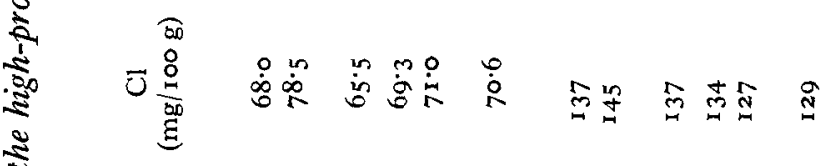

$\approx$

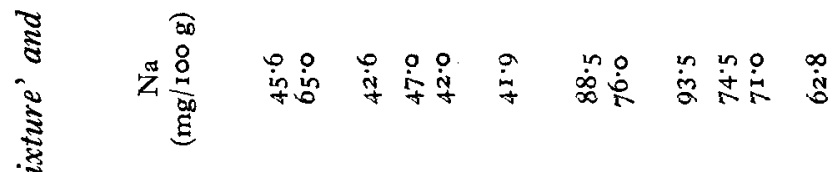

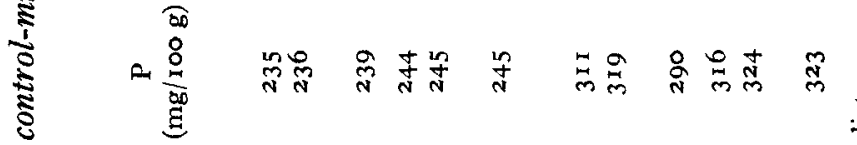

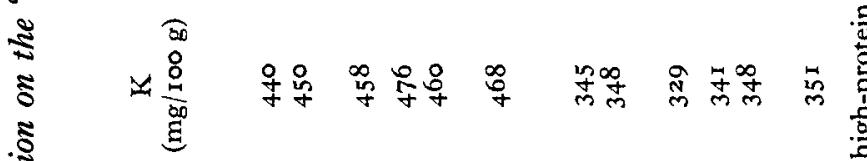

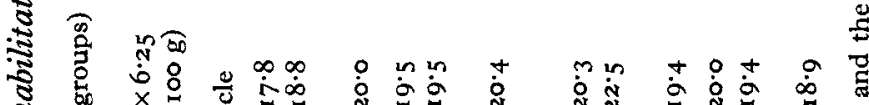

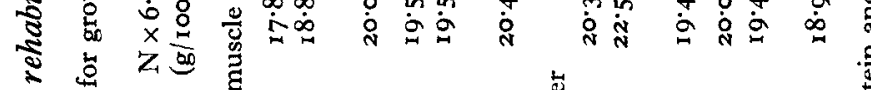

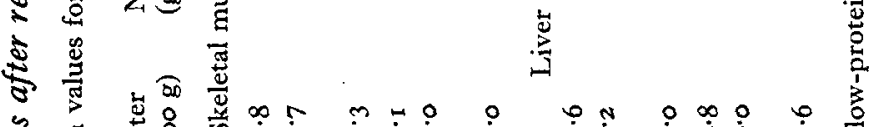

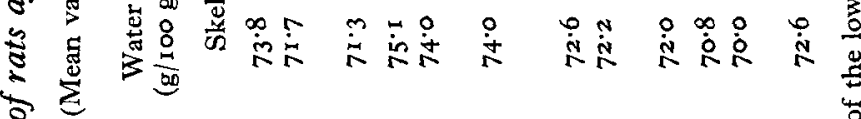

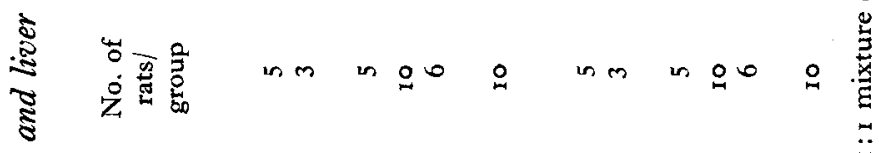

(3)

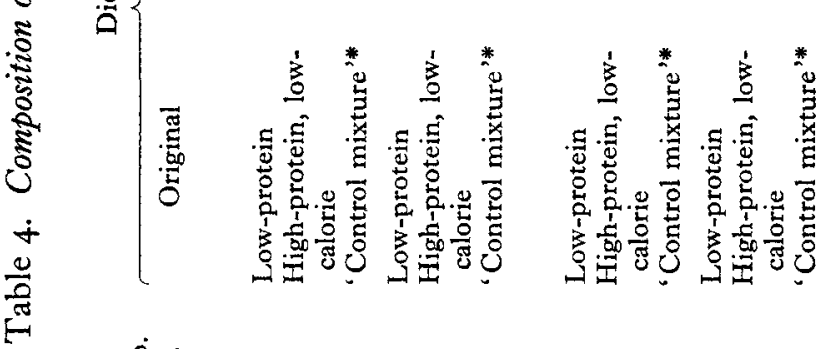

离察 
The values for the liver show similar but greater differences and should be studied in connexion with Table $\mathrm{I}$. The livers of the low-protein animals were smaller and contained a smaller percentage of $\mathrm{N}$ than those of their weight controls on the highprotein, low-calorie diet. This is the usual result of a low-protein as compared with a high-protein diet, and conventional reasoning suggests that there must have been appreciable storage of $\mathrm{N}$ in the liver cells of the high-protein, low-calorie animals and loss of $\mathrm{N}$ from the liver cells of those that had been fed on the low-protein diet. The values give no indication of how the $\mathrm{N}$ was stored and it is conceivable that it was extracellular. Be that as it may, the liver is only a small part of the whole body, and if the values for the rest of the body are considered, and particularly those for the percentage of $\mathrm{N}$ in the fat-free carcasses excluding the liver, it is difficult to find any evidence that the body cells of the low-protein animals contained appreciably less $\mathrm{N}$ than those of the animals in either of the other groups.

The effects of rehabilitation. During rehabilitation all the animals grew well (Figs. I and 2), and any differences there may have been in the composition of the tissues largely disappeared. There was certainly no indication that the low-protein animals stored large amounts of $\mathrm{N}$ without water and $\mathrm{K}$, and without the expected change in weight. This work, therefore, does not provide any evidence in favour of the findings of Holmes et al. (1954) in man, but the results are in complete agreement with those of Stanier (1957) for adult rats maintained on a low-protein diet for a much longer time. It is puzzling why the results for rats and men are so different. It may be because the two species really do react differently to a low-protein diet, or it may be that the diets used for the rats differed in some subtle way from the diets of the Africans they were supposed to imitate. It may be, however, that further work on man, particularly tissue analysis, will not confirm views about the effects of protein deficiency on the composition of the human body.

\section{SUMMARY}

I. The composition of the liver and skeletal muscles and the total nitrogen in the bodies of young rats were investigated after $(a)$ a diet very low in protein, $(b)$ a highprotein diet limited in quantity to maintain the animals at the same weight as those on $\operatorname{diet}(a),(c)$ a 1 : I mixture of the two diets in unlimited amounts.

2. Diet $(a)$ reduced the weight of the liver and the percentage of $\mathrm{N}$ in it, but made no real difference to the composition of the cells of the rest of the body.

3. Rehabilitation after diets $(a)$ and $(b)$ led to growth with deposition of $\mathrm{N}$ in the body cells and a corresponding gain in weight, but no additional storage of $\mathrm{N}$ in the cells without the expected amounts of potassium and water.

We are grateful to Mrs G. Humm, Miss R. Lowings and Mr R. Luff for their valuable technical assistance.

\section{REFERENCES}

Anonymous (1955). Lancet, 269, 707.

FAO/WHO/Josiah Macy Jr. Foundation (1955). Protein Malnutrition. Proceedings of a Conference in famaica (I953). [J. C. Waterlow, editor.] Cambridge University Press.

Gopalan, C., Venkatachalam, P. S. \& Srikantia, S. G. (1953). Metabolism, 2, 335.

Holmes, E. G., Jones, E. R. \& Stanier, M. W. (1954). Brit. F. Nutr. 8, 173. 
King, E. J. (1932). Biochem. F. 26, 292.

McCance, R. A. \& Shipp, H. L. (1933). Spec. Rep. Ser. med. Res. Coun., Lond., no. 187.

McCance, R. A., Widdowson, E. M. \& Shackleton, L. R. B. (1936). Spec. Rep. Ser. med. Res. Coun., Lond., no. $2 \mathrm{I} 3$.

Passmore, R., Meiklejohn, A. P., Dewar, A. D. \& Thow, R. K. (1955). Brit. f. Nutr. 9, 27.

Stanier, M. W. (1957). Brit. F. Nutr. I1, 206.

Trowell, H. C., Davies, J. N. P. \& Dean, R. F. A. (1954). Kwashiorkor. London: Edward Arnold.

\title{
Effect of protein deficiency and subsequent refeeding on body composition of adult rats
}

\author{
BY MARGARET W. STANIER \\ Medical Research Council Department of Experimental Medicine, University o, \\ Cambridge
}

(Received I9 November 1956)

The experiments reported in this paper were undertaken in consequence of some observations made on human subjects in East Africa (Holmes, Jones, Lyle \& Stanier, I956). Poorly nourished Africans appeared to have an increase not only of extracellular fluid but also of the intracellular fluid of the body. Moreover, when such poorly nourished African men were given a good diet, the tissue gain calculated from the observed nitrogen retention (by assuming that the soft tissues consist of $33 \%$ protein) bore no relation to the observed change in body-weight (Holmes, Jones \& Stanier, I954). Although the subjects lost extracellular water (oedema fluid) while taking the good diet, this loss was quantitatively inadequate to account for the anomalous changes in body-weight. A possible explanation of the anomaly is that in severe protein deficiency the cells contain less than the normal concentration of protein and an excess of intracellular fluid; and that during good feeding a simultaneous loss of intracellular water (or fat) might mask the effect on the total body-weight of a gain of intracellular protein.

Although increase of extracellular fluid is a well-known accompaniment of undernutrition, increase of intracellular fluid has seldom been observed. Neither Keys's group in the United States (Keys, Brožek, Henschel, Mickelsen \& Taylor, I950) nor McCance's group in Germany (Widdowson \& McCance, 195I) found such an increase; but it has been suggested that an increase of intracellular fluid may occur in severely undernourished persons in southern India (Gopalan, Venkatachalam \& Srikantia, I953). It is possible that such a change of composition of tissue cells might be a characteristic, not of undernutrition in general, but of the particular type of malnutrition commonly found in Africa and in other underdeveloped regions: a protein deficiency without a corresponding calorie deficiency.

When young growing rats were fed for 2 weeks on a diet very low in protein, and then refed on an adequate diet, there was no apparent change in the composition of the 